\title{
ВЕКТОРИ РЕФОРМУВАННЯ НОТАРІАЛЬНОї ДІЯЛЬНОСТІ: ОКРЕМІ ЦИВІЛЬНО-ПРАВОВІ ТА КРИМІНАЛЬНО-ПРАВОВІ АСПЕКТИ
}

\author{
ОРТИНСЬКИЙ Володимир Львович - доктор юридичних наук, професор, \\ директор Навчально-наукового інституту права, психології та інноваційної освіти \\ Національного університету «Львівська політехніка», Заслужений юрист України \\ ORCID ID: 0000-0001-9041-6330 \\ УДК 340.134 \\ DOI 10.32782/LAW.2020.3.24
}

Статья посвящена анализу базовъхх положений Закона Украинь «О нотариате», в том иисле норм, которьле былли изложень в первоначальной редакиии от 2 сентября 1993 года. Сделан сравнительный анализ с последующими изменениями и дополнениями. Рассмотренъ тендениии законодательного обеспечения нотариальной деятельности в переходнъй период от тотального государственного администрирования, обретения независимости Украинъ к стандартам европейского (латинского) нотариата в государстве.

Ключевъие слова: нотариус, нотариальная деятельность, присяга нотариуса, нотариальная тайна, нотариальнъй округ.

\section{Постановка проблеми}

Історично доведено, що нотаріальна діяльність розвивалася тільки у площині публічної юрисдикції, діяльність, як одна 3 базових інститутів громадянського суспільства, що патронує захист, недоторканність приватної власності, протекцію усіх майнових, інтелектуальних прав і законних інтересів фізичних та юридичних осіб, які звернулися по вчинення нотаріальних дій. Одночасно, така діяльність має і попереджувальне, превентивне забарвлення у форматі системи здійснюваних публічних дій, скерованих на юридичне закріплення безспірних цивільних прав і фактів, тобто результатом якої завжди є посвідчення прав, фактів, що мають юридичне значення.

В Україні сформувалася багатовікова історія діяльності нотаріальних органів.
Умовно можна виокремити наступні етапи становлення та розвитку: у Київській Русі (IX - XII сторіччя), у Галицько-Волинській державі (1199 - 1349 рік), на українських землях у складі Великого князівства Литовського (1340 - 1659 рік), на українських землях у складі Польського Королівства (1387 - 1569 рік) та Речі Посполитої (1569 - 1772 рік). Нотаріальна діяльність в Українській Козацькій державі (1649 - 1783 рік), на українських землях у складі Російської імперії (1783 - 1917 рік), у складі Австрійської та Австро-Угорської імперій (1772 1918 рік), на західноукраїнських землях у складі Польщі (1921 - 1939 рік), в радянській Україні протягом 1917 - 1990 років, у незалежній Україні протягом новітнього періоду.

У представленій публікації зроблено спробу звернутися саме до новітньої істоpiï, тих, здебільшого прогресивних тенденцій розвитку, які мали місце у попереднє десятиріччя, на початку становлення і незалежності України і нотаріального права, законодавства, зокрема.

\section{Стан дослідження}

у своїх наукових пошуках, багато вчених зверталося до питань правового регулювання нотаріальної діяльності, під кутом бачення історико - правової реальності, у площинах конституційного, цивільного та кримінального права, криміналістики, інших галузей знань. Зокрема, до них належать: Т. Аверьянова, I. Аршава, 
П. Андрушко, В. Баранкова, Д. Бараненко, М. Башта, В. Бездрабко, І. Безклубий, Р. Бєлкін, А. Білецький, С. Благовісний, В. Бліхар, I. Бойко, О. Бочан, О. Бунчук, Я. Брайнін, М. Василенко, Т. Варфоломеєва, О. Вінниченко, А. Вінберг, О. Вовк, М. Владимирський-Буданов, М. Гетьманчук, В. Глиняний, Ю. Гошко, В. Гончаренко, Б. Греков, В. Громов, В. Грищук, Г. Грамович, А. Грановський, I. Грозовський, А. Гуледза, П. Гураль, Г. Гулєвська, А. Данюк, Г. Демиденко, М. Демкова, О. Дзера, М. Долинська, Р. Достдар, А. Дячук, М. Дякович, В. Єрмолаєв, Н. Єфремов, А. Єфіменко, Д. Забзалюк, Ю. Заіка, П. Захарченко, Б. Здравомислов, Ю. Золотухін, С. Ізосімов, А. Іщенко, Н. Ільєва, М. Кальницький, М. Кобилецький, Ю. Козьяков, О. Коротюк, А. Кольбенко, В. Комаров, В. Комаров, В. Колесник, Р. Кочерьянц, Н. Клименко, В. Кульчицький, Р. Аащенко, Ф. Аеонтович, П. Аепісевич, В. Аисиченко, В. Макарчук, Х. Майкут, В. Марченко, Р. Максимович, С. Місевич, О. Михайленко, В. Навроцький, М. Настюк, Ю. Нікітін, О. Нелін, М. Никифорак, О. Новаков, М. Оздоєв, С. Орач, Ю. Орзіх, В. Павлов, I. Паньонко, С. Пасічник, Б. Петришак, Н. Пінчук, О. Підопригора, $\lambda$. Радзієвська, В. Рубаник, О. Росинська. М. Салтевський, М. Сегай, С. Семенов, Б. Совенко, В. Степаненко, А. Стрижевська, М. Страхов, І. Терлюк, В. Терентьєв, Б. Тищик, А. Ткач, Г. Трофанчук, I. Усенко, В. Устименко, C. Фурса, E. Фурса, Г. Федущак-Паславська, І. Фріс, С. Харитонов, О. Харитонова, В. Харченко, В. Хашев, Н. Хома, В. Черниш, Р. Шандра, В. Шатіло, В. Шепітько, Ю. Шиндель, О. Шевченко, Ю. Шемшученко Д. Яворницький, А. Яковлів та інші.

\section{Мета дослідження}

Провести фрагментарний моніторинг (тобто у межах дозволеного обсягу наукової публікації), теоретичних і методологічних засад, світоглядних основ процесу подальшого становлення, удосконалення вітчизняного законодавства про нотаріальну діяльність, у контексті сучасних доктрин, які втілювалися у вже новітній період, за попереднє десятиріччя.

\section{Виклад основного матеріалу}

Початок дев'яностих років минулого сторіччя ознаменувався також початком становлення не лише суверенітету та незалежності держави, а й усіх економічних, політико - правових процесів.

3 переходом суспільства до ринкових відносин, законодавчим визнанням рівноправності всіх форм власності, розвитком підприємницької діяльності і процесів приватизації, стало очевидним, що державний нотаріат втрачає своє значення і не може повністю виконувати покладені на нього функції. Поява значної кількості приватних власників передбачає постійний перерозподіл власності, зокрема нерухомості. Із прийняттям, свого часу, Закону «Про власність» та деяких інших, зокрема Закону України «Про заставу», значно розширилася компетенція державних нотаріусів, збільшилась кількість і обсяг нотаріальних дій. Таким чином, формування ринкових відносин обумовило також необхідність проведення радикальної реформи органів нотаріату, який є однією з ланок правової системи. Роль нотаріату в правовому забезпеченні економічних відносин підтверджується світовою практикою. Від якості діяльності нотаріату залежить нормальне функціонування цивільного обороту держави, ефективність охорони і захисту майнових прав та законних інтересів громадян та інших суб’єктів господарювання [1].

Як слушно стверджує А. Давиденко, історія розвитку і реформування нотаріату сучасної незалежної України тісно переплітається з історією двох великих подій, які дали змогу українським нотаріусам самостійно вирішувати свою долю, - прийняття Закону України «Про нотаріат» та заснування Української нотаріальної палати - єдиного всеукраїнського об'єднання нотаріусів (створена 22 квітня 1993 року на конференції нотаріусів та згодом зареєстрована як громадське об'єднання в Міністерстві юстиції України). Ці події суттєво вплинули на життя нотаріату, адже як інститут, який функціонує у сфері перетину приватних i публічних інтересів, нотаріат має володіти організаційною структурою, що відповідала 6 його унікальній природі [2]. 


\section{Цивільне, підприсмницьке, господарське та трудове право}

Прийнятий Верховною Радою України 2 вересня 1993 року Закон України «Про нотаріат» можна порівняти 3 епохальною подією в діяльності нотаріату. Він був фундаментом нотаріальної реформи та чітким вектором для українського нотаріату у бік європейського (латинського) нотаріату.

Хоча на території Західної України ще до 1993 року був відомий інститут приватного нотаріату, загалом можна поділити думку проф. Ю. Козьякова про те, що закон створив правові підстави для впровадження принципово нових, раніше не відомих нашому законодавству інститутів (зокрема приватної нотаріальної діяльності), який уже протягом століть існує у багатьох зарубіжних країнах і показав себе з кращого боку. Розроблений з урахуванням досвіду зарубіжних країн, які визнають латинську школу нотаріату (Німеччина, Франція, Італія тощо), чинний закон реально посилив роль нотаріату у суспільному житті незалежної Української держави, зробив фігуру нотаріуса в системі правозастосування ще вагомішою, підняв на більш високий щабель престиж цієї, без сумніву, цікавої юридичної професії [3].

Вказаний нормативний акт забезпечив перехід від радянського нотаріату до незалежного українського нотаріату. Зокрема, увібрав у себе найкращий світовий досвід щодо здійснення нотаріусами публічно-правової діяльності, зумовив суттеве збільшення кількості приватних нотаріусів, сприяв більшому доступу фізичних та юридичних осіб до нотаріального забезпечення, ввів поняття відповідальності нотаріусів, тобто зупинення і припинення їхньої діяльності у разі допущення порушень тощо [1, с. 294].

Так, Кримінальний кодекс України був доповнений регламентацією стосовно відповідальності за кримінальні правопорушення вчинені нотаріусом. Стаття $232^{1}$ КК України передбачає відповідальність за незаконне використання нотаріусом інсайдерської інформації; стаття 358 КК України, за підроблення нотаріусом документів, печаток, штампів та бланків, збут чи використання підроблених документів, печаток, штампів; стаття $365^{-2}$ КК України, за зловживання повноваженнями особами, які надають публічні послуги, з метою отримання неправомірної вигоди, якщо це завдало істотної шкоди охоронюваним законом правам або інтересам окремих громадян, державним чи громадським інтересам або інтересам юридичних осіб; ч.3 статті $368^{-4}$ КК України, за прийняття пропозиції, обіцянки або одержання нотаріусом неправомірної вигоди для себе чи третьої особи за вчинення дій або бездіяльність 3 використанням наданих їй повноважень в інтересах того, хто пропонує, обіцяє чи надає таку вигоду, або в інтересах третьої особи.

Нові принципи нотаріальної діяльності, які були закладені цим Законом, дали змогу вирішити організаційні проблеми стосовно нотаріального забезпечення суб'єктів цивільно-правових відносин та практично зняти державі із себе більшість організаційних питань і матеріальних витрат у цій сфері [4].

Ще до нових редакцій (відповідно, у 2008, 2015 та 2020 році) самої назви та змісту статті 1 Закону України «Про нотаріат», законодавець визначив власне поняття нотаріату, як систему органів і посадових осіб, на які покладено обов'язок посвідчувати права, а також факти, що мають юридичне значення та вчиняти інші нотаріальні дії, передбачені Законом, 3 метою надання їм юридичної вірогідності [5]. Таким чином, законодавцем у вже згаданій статті, встановлено вичерпний перелік суб'єктів, які мають право вчиняти нотаріальні дії: нотаріуси, які працюють у державних нотаріальних конторах, державних нотаріальних apхівах (державні нотаріуси) або займаються приватною нотаріальною діяльністю (приватні нотаріуси), у сільських населених пунктах нотаріальні дії, також вчиняються уповноваженими на це посадовими особами органів місцевого самоврядування.

Органи, які вправі вчиняти нотаріальні дії, загальновизнано диференціювати на інститути нотаріату (державні та приватні нотаріуси) та квазі-нотаріату (посадові особи органів місцевого самоврядування, інші посадові особи, на які покладено вчинення окремих видів нотаріальних дій відповід- 
но до законодавства). Так, згідно зі статтею 37 Закону, було визначено, що у сільських населених пунктах уповноважені на це посадові особи органу місцевого самоврядування вчиняють нотаріальні дії, зокрема, вживають заходів щодо охорони спадкового майна; посвідчують заповіти (крім секретних); видають свідоцтва про право на спадщину та інші [5].

Важливою властивістю Закону (стаття 34) було чітке окреслення нотаріальних дій, що можуть вчиняти саме нотаріуси. Згодом, у 2012, 2017, 2019 та 2020 роках, цей перелік був доповнений чи деталізований [5].

Порівняльний аналіз повноважень нотаріальних дій, що можуть вчиняти нотаріуси сучасної України за Законом «Про нотаріат» 1993 року та державних нотаріальних контор радянського періоду (ст. 13 Закону УРСР «Про державний нотаріат» 1974 року) призводить до підсумку, що у своїй масі, за кількістю та змістовно-правовим наповненням, вони [повноваження] є однотипними.

Наступним прогресивним постулатом тоді прийнятого Закону було те, що опосередком положень статті 38 (з наступними редакціями у 2003, 2012, 2020 роках), утверджувалася реальна самостійність, незалежність держави. Закон делегував вчинення певних нотаріальних дій до компетенції консульських установ України [5].

Перелік повноважень консульських установ України за Законом України «Про нотаріат» 1993 року, загалом, корелюється 3 переліком нотаріальних дій, що вчиняли консульські установи СРСР (ст. 15 Закону УРСР «Про державний нотаріат» 1974 року (16 видів дій)).

Також Закон встановив права та обов'язки нотаріусів, механізм їх призначення на посаду, відомчу підлеглість.

Новою нормою законодавства стало положення ст. 3 Закону України «Про нотаріат», яке регулює порядок доступу до професії нотаріуса (з наступними змінами та доповненнями у 2012, 2015, 2016, 2019 та 2020 році). Нотаріусом може бути громадянин України, якому присуджено ступінь вищої юридичної освіти не нижче магістра, який володіє державною мовою відповідно до рівня, визначеного Законом України «Про забезпечення функціонування української мови як державної», має стаж роботи у сфері права не менш як шість років, з них помічником нотаріуса або консультантом державної нотаріальної контори - не менш як три роки, склав кваліфікаційний іспит і отримав свідоцтво про право на зайняття нотаріальною діяльністю. Не може бути нотаріусом особа, яка має судимість за вчинення злочину, якщо така судимість не погашена або не знята у встановленому законом порядку (крім реабілітованої особи), особа, дієздатність якої обмежена, або особа, визнана недієздатною [5].

Відповідно до Постанови Верховної Ради України «Про порядок введення в дію Закону України «Про нотаріат» від 2 вересня 1993 р. (п. 3) було встановлено, що без стажування і складання кваліфікаційного іспиту до нотаріальної діяльності допускаються нотаріуси, які на день вступу в силу Закону України «Про нотаріат» (1 січня 1994 року) працювали у державних нотаріальних конторах, а також посадові особи Міністерства юстиції України, управлінь юстиції Ради Міністрів Республіки Крим, обласних, Київської і Севастопольської міських державних адміністрацій, робота яких безпосередньо пов'язана 3 керівництвом та контролем за діяльністю нотаріату.

Реєстрацію приватної нотаріальної діяльності провадили Міністерство юстиції Республіки Крим, управління юстиції обласної, Київської і Севастопольської міських державних адміністрацій. Згодом втратили чинність накази Міністерства юстиції України «Про затвердження Положення про порядок заміщення приватного нотаріуса», «Про затвердження Положення про порядок реєстрації приватної нотаріальної діяльності» та інші. У 2011 році наказом Міністерства юстиції України затверджене нове «Положення про порядок реєстрації приватної нотаріальної діяльності та заміщення приватного нотаріуса» (із змінами від 27.02.2020 року) [6]. 


\section{Цивільне, підприсмницьке, господарське та трудове право}

Нотаріальний округ визначався управлінням юстиції, а робоче місце приватного нотаріуса мало розташовуватися у межах визначеного для нього нотаріального округу. Законодавцем було встановлено обов'язок для приватних нотаріусів приступити до виконання своїх обов'язків на протягом трьох місяців від дня отримання реєстраційного посвідчення, а також укласти договір службового страхування чи внести страхову заставу для забезпечення відшкодування ймовірної шкоди, завданої клієнтам своїми незаконними діями або недбалістю у розмірі стократної мінімальної заробітної плати [6].

Законодавець наділив нотаріусів доволі широким колом прав, які передбачив у статті 4 Закону «Про нотаріат» (доповнена згодом у 2008, 20122015 та 2020 році) [5].

Вагомим доказом рівності між державними та приватними нотаріусами, видається, є положення ст. 6 Закону щодо складання нотаріальної присяги. Особа, якій вперше надається право займатися нотаріальною діяльністю, у відповідному територіальному органі Міністерства юстиції України в урочистій обстановці складає присягу.

Збереженню нотаріальної таємниці, тобто сукупності відомостей, отриманих під час вчинення нотаріальної дії або звернення до нотаріуса заінтересованої особи, в тому числі про особу, іiі майно, особисті майнові та немайнові права і обов'язки, законодавцем присвячено окрему ст. 8 Закону.

Від своєї первинної редакції, стаття отримала цілу низку змін та доповнень, останні $з$ яких відбулися прийнятими Законами України «Про внесення змін до деяких законодавчих актів України щодо забезпечення ефективності інституційного механізму запобігання корупції» від 2 жовтня 2019 року та «Про внесення змін до Закону України «Про нотаріат» щодо усунення законодавчих колізій та прогалин» від 14 липня 2020 року.

Нотаріусом протягом десяти робочих днів на обгрунтовану письмову вимогу суду, прокуратури, органів, що здійснюють оперативно-розшукову діяльність, органів досудового розслідування у зв'язку з кримінальним провадженням, цивільними, господарськими, адміністративними справами, справами про адміністративні правопорушення, що знаходяться в провадженні цих органів, 3 обов'язковим зазначенням номера справи та прикладенням гербової печатки відповідного органу, а також на обгрунтовану письмову вимогу державного виконавця, приватного виконавця за виконавчим провадженням 3 обов'язковим зазначенням номера виконавчого провадження та реквізитів виконавчого документа, на підставі якого здійснюється виконавче провадження Національному агентству $з$ питань запобігання корупції на його письмовий запит, здійснений $з$ метою виконання повноважень, визначених Законом України «Про запобігання корупції». Довідки про суму нотаріально посвідчених договорів, які необхідні виключно для встановлення додержання законодавства 3 питань оподаткування, надаються нотаріусом протягом десяти робочих днів на обгрунтовану письмову вимогу податкового органу, засвідчену гербовою печаткою такого органу [7].

Також важливе значення для здійснення нотаріальної діяльності мали нормист. 98 Закону України «Про нотаріат», згідно 3 якими нотаріуси застосовують норми іноземного права відповідно до законодавства України, міжнародних договорів. Нотаріусам дозволено приймати документи, складені відповідно до вимог іноземного права, та робити посвідчувальні написи за формою, передбаченою іноземним законодавством, у випадку, якщо це не суперечить законодавству України [5].

\section{Висновки}

Закон України «Про нотаріат», без перебільшення, можна вважати «історичною віхою» для подальшого розвитку, модернізації системи органів, які вчиняють нотаріальні дії; для галузі права; для галузі законодавства та, звісно, для науки, навчального процесу, зокрема.

Закон сприяв безперешкодному доступу громадян до нотаріального забезпечення, корелював повноваження державних 


\section{АНОТАЦІЯ}

Стаття присвячена аналізу базових положень Закону України «Про нотаріат», у тому числі норм, які були викладені у первинній редакиіӥ від 2 вересня 1993 року. Зроблено порівняльний аналіз із наступними змінами та доповненнями. Розглянуто тенденциї законодавчого забезпечення нотаріальної дiяльності у перехідний період від тотального державного адміністрування, здобуття незалежності України до стандартів європейсъкого (латинсъкого) нотаріату в державі.

та приватних нотаріусів у вчиненні нотаріальних дій, підвищив професійні вимоги, посилив гарантії діяльності нотаріуса та правового режиму нотаріальної таємниці. Забезпечив реалізацію конституційної норми щодо судового контролю за законністю вчинених нотаріальних дій, окреслив інститут відповідальності нотаріусів, тобто зупинення і припинення їхньої діяльності у разі допущення порушень.

\section{Мітература}

1. Долинська М. Становлення та розвиток законодавства про нотаріальну діяльність в Україні: дис. ... докт. юрид. наук: 12.00.01 / Львівський національний університет імені Івана Франка. Аьвів, 2017. C. $290-291$.

2. Давиденко А. О. Історія виникнення нотаріату в Україні. Вісник Запорізъкого наиіонального університету. 2010. № 4. С. 23 - 28.

3. Козьяков Ю. М. Нотаріат. Історія i сучасність (короткий огляд). Нотарiam для Bac. 1998. № 1. С. $13-16$.

4. Шишленко В. Г. Щодо реформування нотаріату України. Форум права. 2012. № 1 . C. $1092-1098$.

5. Про нотаріат: Закон України від 02.09.1993. База даних «Законодавство України». Верховна Рада України. URL: https://zakon.rada.gov.ua/laws/show/3425-12.

\section{SUMMARY}

The article is devoted to the analysis of the basic provisions of the Law of Ukraine 'On the notary', including the norms, which were set out in the original version from September 2, 1993. A comparative analysis was made with the following changes and additions. There were considered tendencies of legislative support of notarial activity in the transition period from the total state administration, gaining the independence of Ukraine to the standards of the European (Latin) notary in the state.

The normative legal act was analyzed, from the point of view of further development, modernization of the system of bodies and officials who perform notarial acts; for the field of law; for the field of legislation, for science, the educational process, in particular.

6. Положення про порядок реєстрації приватної нотаріальної діяльності: наказ Міністра юстиції України від 4.03.1994. URL: https:// https://zakon.rada.gov.ua/laws/ show/z0041-94. Наказ втратив чинність на підставі Наказу Міністерства юстиий.№ 2151/5 від 12.12.2008 року; Положення про порядок реєстрації приватної нотаріальної діяльності та заміщення приватного нотаріуса: наказ Міністра юстиції України від 22.03.2011. № 871/5. URL: https://zakon. rada.gov.ua/laws/show/z0388.

7. Про внесення змін до деяких законодавчих актів України щодо забезпечення ефективності інституційного механізму запобігання корупції: Закон України від 02.10.2019. База даних «Законодавство України». Верховна Рада України. URL: https://zakon.rada.gov.ua/laws/show/14020; Про внесення змін до Закону України «Про нотаріат» щодо усунення законодавчих колізій та прогалин: Закон України від 14 липня 2020. База даних «Законодавство України». Верховна Рада України. URL: https://zakon.rada.gov.ua/laws/show/77520\#n33. 